\title{
Growth of Fraser Fir Christmas Trees In Response to Annual Shearing
}

\section{Eric Hinesley and Scott A. Derby \\ Department of Horticultural Science, North Carolina State University, Raleigh, NC 27695-7609}

Additional index words. biomass, needle length, needle area, needle weight, Abies fraseri, USDA grade

\begin{abstract}
Fraser fir [Abies fraseri (Pursh) Poir.] Christmas trees were sheared once annually over a 4-year period using fixed schedules ranging from July to March. Shearng in July reduced potential growth of the upper crown by $38 \%$; when done in October or March, the reduction was about 50\%. Length, dry weight, and one-sided area of individual needles were smallest on nonsheared trees, and increased to maximum values on trees sheared in March. In the upper crown (top three internodes), trees sheared in July were 16\% to 33\% heavier than those sheared in August or later. Dry matter in the upper crown was $30 \%$ foliage and $70 \%$ woody material. Sixty-one percent of the biomass in the upper crown was branches for trees sheared in July, compared to 55\% for October. In the upper crown, foliage comprised about $50 \%$ of the branch dry weight (all treatments); in 3-year-old branches, it was $54 \%$ to $58 \%$. Among treatments, shearing in July caused the smallest reduction of potential growth and yielded the largest and heaviest branches with significantly more foliage and lateral shoots, all of which would be expected to improve crown density and commercial value. October was the least favorable time to shear.
\end{abstract}

Fraser fir (Abies fraseri) is a valuable Christmas tree species indigenous to isolated mountain tops in western North Carolina, eastern Tennessee, and southwestern Virginia. Christmas trees acquire their dense, conical shape as a result of annual pruning or shearing. True firs (Abies Mill.) are sheared once annually (Douglass, 1983; Whitfield, 1977), whereas faster growing species, e.g., virginia pine (Pinus virginiana $\mathrm{L}$.), in warmer climates are sheared two or three times (Brown, 1979; Davis, 1972). An important issue is when to shear for best growth and quality.

The shearing season varies by species. Eastern white pine (Pinus strobus L.) has a narrow window of time for successful shearing (Whitfield, 1977). Virginia pine can form adequate numbers of buds on the current-year shoots when pruned throughout the summer (Brown, 1979; Davis, 1972). Abies can be sheared almost year-round, but middle to late summer shearing normally yields the best quality trees (Brown and Heiligmann, 2002; Douglass, 1983; Hinesley and Derby, 2004; Powell, 1982). Beyond that general observation, few specific growth effects resulting from pruning at different times have been documented, e.g., quantity and distribution of foliage; number, size, and distribution of branches; and allocation of growth to stems, branches, and foliage. Our objective was to examine the growth and distribution of dry matter in Fraser fir Christmas trees in response to annual shearing on different dates.

Received for publication 16 July 2003. Accepted for publication $8 \mathrm{Feb}$. 2004. We thank the staff of the Upper Mt. Res. Sta., Laurel Springs, N.C. for maintaining the experiment and assisting in collection of data. This research was funded in part by the North Carolina Agricultural Research Service, Raleigh.

\section{Materials and Methods}

The experiment was initiated in early August 1998 in a stand of fraser fir (1 to 1.3 $\mathrm{m}$ tall, spacing $1.5 \times 1.5 \mathrm{~m}$ ) Christmas trees on the Upper Mountain Research Station near Laurel Springs, N.C. (lat. $36^{\circ} 24^{\prime} N$, long. $81^{\circ} 18^{\prime} \mathrm{W}$ ). Soil was a Watauga loam (Typic hapludult, fine-loamy, mesic; elevation about $1,000 \mathrm{~m}$, southwest aspect). Trees were grown with conventional cultural practices.

Five shearing schedules were used: control (nonsheared), late July, late August or early September, mid-October, and March. At the outset, trees were excluded if they were too small or off color. Acceptable trees were assigned to blocks, and treatments were randomly assigned to single-tree plots in each block. The experimental design was a randomized complete block, initially with 50 blocks (five trees per block). During the investigation some trees were omitted owing to damage from birds, insects, disease, and nutritional problems, or failure to produce a normal leader.

The first year, trees within various treatments were sheared by cutting the terminal leader to about $30 \mathrm{~cm}$, and shortening the branches in the top whorl to half the length of the sheared leader. Below the top whorl the distal tip was removed from all major branches in the tree crown including the branch measured previously. Some trees with leaders shorter than $32 \mathrm{~cm}$ were not sheared in 1999 and eventually were excluded from the analysis. Shearing treatments were repeated according to schedule in 1999, 2000, and March 2001. No shearing occurred after the 2001 growing season to impart a more natural appearance, as in the year of harvest.

Needle measurements. On 20 Nov. 2001, needles were sampled on a dominant 2-year-old branch on each tree using methods previously described for fraser fir (Brewer et al., 1992).
One current-year needle and one 2-year-old needle were taken from a dominant 2-yearold branch on each tree. Foliage is typically in a decussate (2-ranked) configuration with the largest needles attached to the abaxial (lower) side of the branch, mid-way between the proximal (inner) and distal (outer) ends of the internode (Brewer et al., 1992). One large needle was collected at that position in each internode. Needles were taped to labeled sheets of white paper, and stored in sealed freezer bags on ice. The next day, sheets were photocopied to preserve the images. Sheets, with needles attached, were dried at $65^{\circ} \mathrm{C}$, and needles weighed to the nearest $0.1 \mathrm{mg}$. Length and projected area were determined for each image using a Monochrome Agvision System area meter (Decagon Devices, Pullman, Wash. with DIAS II software (version 1.0, about 1989). Projected areas were multiplied by 1.145 to correct for the elliptical upper surface of needles (Brewer et al., 1992) .

During winter(2000-01) twolarge branches (first-order laterals, 3 years old, opposite sides of the trunk) were selected at the top of the 1998 internode (25 trees/treatment), cut flush with the trunk, tagged, and placed in a nylon or burlap bag. The trunk was cut at the base of the 1999 internode, and all biomass above the cut was bagged with the two large side-branches. Material was transported to Raleigh, and stored at $-1{ }^{\circ} \mathrm{C}$.

Processing large branches. After measuring basal diameter (two directions), each of the two large branches from each tree was subdivided into shoot segments, by age (1,2, and 3 years), and the number of segments counted. Segments were combined, by age, for each branch. After drying to constant weight at $65^{\circ} \mathrm{C}$, foliage and woody material were separated and weighed for each sample. Averages were computed for the two branches from each tree. Stem segments were processed similarly.

Processing the upper crown. For each tree, branches were removed, counted, and segregated for each of the three internodes. Leaders were counted and combined into one sample. Samples were dried at $65{ }^{\circ} \mathrm{C}$, partitioned into wood and foliage, and weighed. Total dry weight was the sum of woody and foliar components.

Statistical analysis. Data were analyzed with general linear model (GLM) procedures (SAS Institute, Inc., 1990). Linear contrasts (1 df) were used to make certain treatment comparisons.

\section{Results}

Large branches. Shearing reduced branch growth (Table 1). Basal diameter and crosssectional area of 3-year-old branches on nonsheared trees averaged $13 \%$ and $27 \%$ greater, respectively, than branches sheared in July. These differences were $24 \%$ and $54 \%$, respectively, for trees sheared in August and October. Although July shearing yielded significantly larger branch diameters than August or October, average diameters for early shearing (July and August) versus later shearing (October and March) were not different (Table 
Table 1. Biomass and number of shoots on 3-year-old branches of fraser fir Christmas trees sheared on various schedules. ${ }^{\mathrm{z}}$

\begin{tabular}{|c|c|c|c|c|c|c|c|}
\hline \multirow[b]{2}{*}{$\begin{array}{l}\text { Shearing } \\
\text { date }^{y}\end{array}$} & \multirow[b]{2}{*}{$\begin{array}{c}\text { No. of } \\
\text { trees }\end{array}$} & \multirow{2}{*}{$\begin{array}{c}\text { Branch } \\
\text { diam } \\
(\mathrm{mm})\end{array}$} & \multicolumn{3}{|c|}{ Branch dry wt } & \multicolumn{2}{|c|}{ Branch segments } \\
\hline & & & $\begin{array}{c}\text { Wood } \\
(\mathrm{g})\end{array}$ & $\begin{array}{c}\text { Foliage } \\
(\mathrm{g})\end{array}$ & $\begin{array}{c}\text { Total } \\
(\mathrm{g})\end{array}$ & $\begin{array}{c}\text { 1-year-old } \\
\text { (no.) }\end{array}$ & $\begin{array}{c}\text { 2-year-old } \\
\text { (no.) }\end{array}$ \\
\hline Nonsheared (control) & 22 & 15.8 & 66 & 81 & 147 & 89 & 21.2 \\
\hline July & 24 & 14.0 & 41 & 51 & 92 & 51 & 9.3 \\
\hline August & 25 & 12.7 & 30 & 41 & 71 & 34 & 8.2 \\
\hline October & 23 & 12.7 & 26 & 32 & 58 & 25 & 6.4 \\
\hline March & 25 & 13.4 & 33 & 39 & 72 & 26 & 7.7 \\
\hline Control vs. sheared & & $* *$ & $* *$ & $* *$ & $* *$ & $* *$ & $* *$ \\
\hline July vs. Aug. & & $* *$ & $* *$ & $* *$ & $* *$ & $* *$ & NS \\
\hline August vs. October & & NS & NS & $*$ & NS & $*$ & $*$ \\
\hline October vs. March & & NS & $*$ & NS & $*$ & NS & NS \\
\hline July and August vs. later & & NS & $* *$ & $* *$ & $* *$ & $* *$ & $* *$ \\
\hline
\end{tabular}

${ }^{2}$ Values are means based on two branches per tree.

'Sheared on these schedules the last 4 years before harvest.

NS,**** Nonsignificant or significant at $P<0.05$ or 0.01 , respectively.

Table 2. Dry weight of wood and foliage in the top three internodes of fraser fir Christmas trees sheared on various schedules. ${ }^{\mathrm{z}}$

\begin{tabular}{|c|c|c|c|c|c|c|c|c|}
\hline \multirow[b]{2}{*}{$\begin{array}{l}\text { Shearing } \\
\text { date }^{y}\end{array}$} & \multirow[b]{2}{*}{$\begin{array}{c}\text { No. of } \\
\text { trees }\end{array}$} & \multirow[b]{2}{*}{$\begin{array}{l}\text { Stem } \\
(\mathrm{g})\end{array}$} & \multicolumn{3}{|c|}{ Branches } & \multicolumn{3}{|c|}{ Total } \\
\hline & & & $\begin{array}{c}\text { Wood } \\
(\mathrm{g})\end{array}$ & $\begin{array}{c}\text { Foliage } \\
(\mathrm{g})\end{array}$ & $\begin{array}{c}\text { Total } \\
(\mathrm{g})\end{array}$ & $\begin{array}{c}\text { Wood } \\
(\mathrm{g})\end{array}$ & $\begin{array}{c}\text { Foliage } \\
(\mathrm{g})\end{array}$ & $\begin{array}{c}\text { Total } \\
(\mathrm{g})\end{array}$ \\
\hline Nonsheared (control) & 22 & 480 & 378 & 392 & 770 & 850 & 400 & 1250 \\
\hline July & 24 & 307 & 238 & 238 & 475 & 532 & 250 & 782 \\
\hline August & 25 & 273 & 190 & 209 & 399 & 450 & 222 & 672 \\
\hline October & 23 & 265 & 160 & 162 & 321 & 412 & 175 & 586 \\
\hline March & 25 & 286 & 171 & 174 & 346 & 441 & 191 & 632 \\
\hline Control vs. sheared & & $* *$ & $* *$ & $* *$ & $* *$ & $* *$ & $* *$ & $* *$ \\
\hline July vs. August & & NS & $*$ & NS & $*$ & $* *$ & NS & $*$ \\
\hline August vs. October & & NS & NS & $*$ & $*$ & NS & $*$ & NS \\
\hline October vs. March & & NS & NS & NS & NS & NS & NS & NS \\
\hline July and August vs. later & & NS & $* *$ & $* *$ & $* *$ & $*$ & $* *$ & $* *$ \\
\hline
\end{tabular}

${ }^{2}$ Values are means based on two branches per tree.

${ }^{y}$ Sheared on these schedules the last 4 years before harvest.

NS,*,**Nonsignificant or significant at $P<0.05$ or 0.01 , respectively.

1). Branches sheared in July had $37 \%$ less dry weight than nonsheared trees; the difference was $51 \%$ to $60 \%$ for August, October, and March. July shearing had $43 \%$ fewer 1 -yearold shoots and $56 \%$ fewer 2-year-old shoot segments compared to nonsheared controls. However, the July shearing yielded 50\% more current-year shoots than the next best shearing treatment (August) (Table 1).

Top three internodes. Shearing reduced total biomass in the upper crown (Table 2). In the top three internodes, nonsheared trees had $60 \%$ more stems, branches, foliage than the July shearing treatment; differences were even greater for later shearing dates (Table 2). Trees sheared in July were $16 \%$ to $33 \%$ heavier in the top three internodes, compared to those sheared in August, or later. Total biomass was smallest (47\% of control) for October shearing.

Shearing also affected the distribution of biomass in the top three internodes (Table 2). Woody material comprised about $70 \%$ of the total dry matter (all treatments), leaving 30\% in foliage. Stems were $38 \%$ to $40 \%$ of the total biomass (upper crown) in nonsheared trees as well as trees sheared in July or August. The proportion in stems increased to $45 \%$ for late shearing dates. Conversely, $62 \%$ of the dry matter in nonsheared trees was branches (wood + foliage) — similar to July shearing. Trees sheared in October contained $55 \%$ of their biomass in branches. Foliage was $50 \%$ of the branch dry weight within the top three internodes (sheared and nonsheared) (Table 2), compared to $55 \%$ to $58 \%$ in 3-year-old branches (Table 1).

Foliage. Weight, length, and one-sided area of individual needles were smallest on nonsheared control trees, and increased to maximum values on trees sheared in October or March (Table 3). March shearing yielded individual current-year (1-year-old) needles with $86 \%, 50 \%$, and $70 \%$ more dry weight, length, and one-sided area, respectively, than nonsheared trees. Needle length and projected area for trees sheared in July were similar to those of nonsheared trees, whereas dry weight was significantly greater. Dimensions of the 2-year-old needles were similar to those of current-year needles (Table 3 ).

\section{Discussion}

Christmas trees can be regarded as a foliage crop because crown density and quality depend largely on the quantity and appearance of foliage, and the manner in which it is displayed on branches. Thus, it is desirable to maximize the mass and uniformity of foliage and branches within the crown since uniformly dense trees generally have the greatest value (U.S. Dept. of Agriculture, 1989). Although nonsheared leaders can exceed $0.8 \mathrm{~min} 1$ year, they are normally pruned to about $0.3 \mathrm{~m} \cdot$ year $^{-1}$, possibly $0.5 \mathrm{~m}$ maximum when trees are $<1.5 \mathrm{~m}$ tall. Growth of nonsheared trees can far exceed that of sheared trees (Tables 1 and 2), but sheared trees have greater crown density, are more uniform, and generally have greater commercial value.

Nonsheared (natural) Fraser firs tend to have long stem internodes, distinct tiers of branches, and low crown density. However, exceptional trees sometimes exhibit rapid

Table 3. Dry weight, length, and one-sided area of individual 1- and 2-year-old needles from fraser fir Christmas trees sheared on various dates. ${ }^{2}$

\begin{tabular}{|c|c|c|c|c|c|c|}
\hline \multirow[b]{2}{*}{$\begin{array}{l}\text { Shearing } \\
\text { date }^{y}\end{array}$} & \multicolumn{3}{|c|}{ 1-year-old } & \multicolumn{3}{|c|}{ 2-year-old } \\
\hline & $\begin{array}{c}\mathrm{Wt} \\
(\mathrm{mg})\end{array}$ & $\begin{array}{c}\text { Length } \\
(\mathrm{mm})\end{array}$ & $\begin{array}{l}\text { Area } \\
\left(\mathrm{cm}^{2}\right)\end{array}$ & $\begin{array}{c}\mathrm{Wt} \\
(\mathrm{mg})\end{array}$ & $\begin{array}{c}\text { Length } \\
(\mathrm{mm})\end{array}$ & $\begin{array}{l}\text { Area } \\
\left(\mathrm{cm}^{2}\right)\end{array}$ \\
\hline Nonsheared (control) & 8.2 & 18.6 & 0.40 & 8.2 & 19.2 & 0.40 \\
\hline July & 9.6 & 21.4 & 0.48 & 9.7 & 20.3 & 0.45 \\
\hline August & 12.6 & 26.0 & 0.60 & 12.8 & 24.4 & 0.59 \\
\hline October & 14.8 & 27.7 & 0.68 & 13.7 & 25.2 & 0.61 \\
\hline March & 15.3 & 28.0 & 0.68 & 14.2 & 25.5 & 0.62 \\
\hline Control vs. sheared & $* *$ & $* *$ & $* *$ & $* *$ & $* *$ & $* *$ \\
\hline July vs. August & $* *$ & $* *$ & $* *$ & $* *$ & $* *$ & $* *$ \\
\hline August vs. October & $* *$ & $*$ & $* *$ & NS & NS & NS \\
\hline October vs. March & NS & NS & NS & NS & NS & NS \\
\hline July and August vs. later & $* *$ & $* *$ & $* *$ & $* *$ & $* *$ & $* *$ \\
\hline
\end{tabular}

${ }^{\mathrm{z}}$ Values are means based on one needle of each age class from a 2-year-old branch on each tree. ${ }^{y}$ Sheared on these schedules the last 4 years before harvest.

NS,*,**Nonsignificant or significant at $P<0.05$ or 0.01 , respectively. 
growth rate and high crown density even without shearing. Sheared trees are more compact, without obvious gaps or tiered crown structure, and have greater and more uniform crown density. Although shearing is necessary to produce Christmas trees with dense crowns, it reduced potential tree growth by $37 \%$ (July) to $53 \%$ (October) (Table 2). While some reduction in growth was expected, the extent was surprising. When trees are subjected to bud and/or foliage loss, either by clipping or feeding by herbivores, tree response can vary considerably by species, nutritional status, competitive status, severity of treatment as well as timing, method, and frequency of pruning and/or defoliation (Hawkins and Henry, 1999; Margolis et al., 1988; Puettmann and Saunders, 2001). Shearing treatments used in this study represented a light pruning, i.e., in most cases, only the distal tips of branches were removed. Heavier pruning would have removed a larger portion of the shoots and buds, and likely resulted in even larger losses of potential growth.

Separation of the entire upper crown into stems, branches, and foliage provided a good measure of tree response to shearing. When subjected to pruning and defoliation, individual branches often respond as autonomous units (Långström et al., 1990; Watson and Casper, 1984); thus significant variation can occur among branches, even within the same whorl. This generalization also applies to foliage (Morgan et al., 1983).

Treatment differences were not only reflected in total biomass but also in branch counts. The fact that nonsheared trees had the maximum number of 1- and 2-year-old segments on large side-branches (Table 1) merely reflected that those branches were not sheared, and were thus longer than sheared shoots. Since bud density is highest on the distal half of the shoot (Powell, 1982), retaining that portion (no shearing) preserves the highest potential branch density, assuming no compensatory effect in the proximal part of sheared branches. Among the shearing treatments, shearing in July yielded $28 \%$ to $58 \%$ more foliage and twice as many current-year shoots on 3-yearold branches (midcrown), compared to October or March (Table 1). Thus, it appears that early shearing improved crown density.

Although shearing affected total foliage weight, the most dramatic manifestation appeared in the size of individual needles (Table 3). Trees sheared in October or March had much larger needles than nonsheared trees or trees sheared earlier. Consequently, it was possible to visually distinguish many trees in the two latest shearing treatments. Based on total foliage weight and number of branch segments in the upper crown, i.e., greater for nonsheared and early-sheared trees (Table 1), and noting that the dimensions of individual needles (Table 3 ) are inversely related to total needle weight in the upper crown (Table 2), it appears that needle size varies in a manner that tends to maintain constant foliage weight and area on the tree. Evidently, needle size was not a major factor in tree quality because July and August shearing yielded the best average quality (Hinesley and Derby, 2004).

In addition to total biomass, shearing also affected allocation of growth among biomass components in the upper crown. The proportion in stems increased from $40 \%$ in July to 45\% for late shearing in October and March. In the upper crown about $30 \%$ of the total dry matter was foliage. Foliage comprised $55 \%$ of the dry weight in 3-year-old branches (Table 1). An earlier study estimated that $42 \%$ of the aboveground biomass was foliage in 2.5-m trees (Hinesley and Wright, 1989).

Shoot elongation for determinant species is related to bud size (Kozlowski, 1973; Little, 1970), so leaving a small bud (late shearing) will result in less shoot elongation the following year, as confirmed by field measurements (Jeff Owen, N.C. Coop. Ext. Serv., unpublished data). Shearing in July and August allows additional bud growth during late summer and fall, resulting in bigger, more vigorous shoots the following year. In October or March buds are already developed for the current year, and have little potential for additional growth. Thus, compensatory growth likely occurs through an increase in the size of existing cells following budbreak rather than an increase in the number of cells the previous summer and fall.

Response to shearing treatments, and the subsequent effect(s) on tree quality, can vary dramatically among individual trees, particularly where there are big differences in bud density on leaders (Brown and Heiligmann, 2002). Despite considerable variation among trees within treatments, trees sheared in July and August had the best average quality; those sheared in October or March were lower quality (Hinesley and Derby, 2004). Other studies with West Virginia balsam fir (Abies balsamea var. phanerolepis) and fraser fir have yielded similar conclusions (Brown and Heiligmann 2001). In our study, trees sheared in July and August also had the greatest biomass, excluding nonsheared trees; thus, differences in quality might be related to the smaller reduction in potential growth associated with early shearing.

\section{Literature Cited}

Brewer, J.F., L.E. Hinesley, and L.K. Snelling. 1992. Foliage attributes for current-year shoots of fraser fir. HortScience 27:920-925.

Brown, Jr., G.F. 1979. Shearing response of virginia pine. Amer. Christmas Tree J. 23(2):49-51.

Brown, J.H. and R.B. Heiligmann. 2002. Shearing west virginia balsam (Canaan) and fraser fir for Christmas trees. Ohio Agr. Res. Dev. Ctr., Ohio State Univ. (Wooster) Spec. Circ. 188.

Davis, T.S. 1972. Pruning techniques for producing southern pine Christmas trees. Ga. Agr. Expt. Sta. Res. Bul. 124.

Douglass, B.S. 1983. Noble fir shearing and fertilizer study. Christmas Tree Lookout 16(3):30-32, 34, 36, 38, 40. Pacific N.W. Christmas Tree Assn., Salem, Ore.

Hawkins, B.J. and G. Henry. 1999. Nutrition and bud removal affect biomass and nutrient allocation in douglas-fir and western red cedar. Tree Physiol. 19:197-203.

Hinesley, L.E. and S.A. Derby. 2003. Shearing date affects growth and quality of fraser fir Christmas trees. HortScience 39:1020-1024.

Hinesley, L.E. and R.D. Wright. 1989. Biomass and nutrient accumulation in fraser fir Christmas trees. HortScience 24:280-282.

Kozlowski, T.T. 1973. Predictability of shoot length from bud size in Pinus resinosa Ait. Can. J. For. Res. 3:34-38.

Långström, B., O. Tenow, A. Ericsson, C. Hellqvist, and S. Larsson. 1990. Effects of shoot pruning on stem growth, needle biomass, and dynamics of carbohydrates and nitrogen in scots pine as related to season and tree age. Can. J. For. Res. 20:514-523.

Little, C.H.A. 1970. Apical dominance in long shoots of white pine (Pinus strobus). Can. J. Bot. 48:239-253.

Margolis, H.A., R.R. Gagnon, D. Pothier, and D.P. Marius. 1988. The adjustment of growth, sapwood area, heartwood area, and sapwood saturated permeability of balsam fir after different intensities of pruning. Can. J. For. Res. 18:723-727.

Morgan, M.G., D.A. MacLean, and H. Piene. 1983. Variation in balsam fir needle length due to crown position, foliage age, and intertree differences. For. Sci. 29:412-422.

Powell, G.R. 1982. Shoot and bud development in balsam fir: Implications for pruning of Christmas trees. For. Chronicle 58:168-172.

Puettmann, K.J. and M.R. Saunders. 2001. Patterns of growth compensation in eastern white pine (Pinus strobus L.): The influence of herbivory intensity and competitive environments. Oecologia 129:376-384.

SAS Institute, Inc. 1990. SAS/STAT user's guide. vol. 2. SAS Inst., Inc. Cary, N.C.

U.S. Department of Agriculture. 1989. United States standards for grades of Christmas trees: Revised, effective 30 Oct. 1989.U.S. Dept. Agr., Agr. Mktg. Serv., Wash., D. C. (FR Doc. 89-23043).

Watson, M.A. and B.B.Casper. 1984. Morphogenetic constraints on pattern of carbon distribution in plants. Annu. Rev. Ecol. Syst. 15:233-258.

Whitfield, F.E. 1977. Growing Christmas trees in North Carolina. N.C. Agr. Ext. Serv. (Raleigh) Publ. AG-95. 